\title{
Jaguar (Panthera onca Linnaeus, 1758) roadkill in Brazilian Atlantic Forest and implications for species conservation
}

\author{
Srbek-Araujo, AC. ${ }^{a, b *}$, Mendes, SL. ${ }^{c}$ and Chiarello, $A G{ }^{d}$ \\ aPrograma de Pós-Graduação em Ecologia de Ecossistemas, Universidade Vila Velha - UVV, \\ Rua Comissário José Dantas de Melo, 21, Boa Vista, CEP 29102-920, Vila Velha, ES, Brazil \\ bPrograma de Pós-Graduação em Ecologia, Conservação e Manejo de Vida Silvestre, \\ Instituto de Ciências Biológicas, Universidade Federal de Minas Gerais - UFMG, \\ Avenida Antônio Carlos, 6627, Pampulha, CEP 31270-901, Belo Horizonte, MG, Brazil \\ 'Programa de Pós-Graduação em Biologia Animal, Centro de Ciências Humanas e Naturais, \\ Universidade Federal do Espírito Santo - UFES, Avenida Marechal Campos, 1468, Maruípe, \\ CEP 29043-900, Vitoria, ES, Brazil \\ ${ }^{\mathrm{d}}$ Departamento de Biologia, Faculdade de Filosofia Ciências e Letras de Ribeirão Preto, \\ Universidade de São Paulo - USP, Avenida dos Bandeirantes, 3900, CEP 14040-901, Ribeirão Preto, SP, Brazil \\ *e-mail: srbekaraujo@hotmail.com
}

Received: October 10, 2013 - Accepted: February 20, 2014 - Distributed: August 31, 2015

(With 1 figure)

\begin{abstract}
We report the roadkill of a jaguar in one of the longest highways in Brazil (BR-101), in the stretch where this road crosses one of the most important Atlantic Forest remnants in the country: the Linhares-Sooretama block. The jaguar population present in this area represents the very last in entire Espírito Santo state. There is an approved project to the lines duplication of the entire BR-101 Highway and the company responsible by the work has already started the first activities in the state. However, there is no environmental impact assessment already done neither planning for the implementation of measures to avoid or reduce the roadkill risk in the region. Thus, to minimize the impacts associated with the BR-101, we do not recommend its lines duplication along the $15 \mathrm{~km}$ stretch traversing the LinharesSooretama block. In addition, alternatively, we suggest the deviation of the current route of the BR-101 Highway or the construction of overpasses to fauna in the most critical points, interspersing these overpasses with electronic speed monitoring devices and warning and educational plates.
\end{abstract}

Keywords: big cats, management, monitoring, protected area, threatened species.

\section{Atropelamento de onça-pintada (Panthera onca Linnaeus, 1758) na Mata Atlântica brasileira e implicações para a conservação da espécie}

\begin{abstract}
Resumo
A presente comunicação reporta o atropelamento e morte de uma onça-pintada na Rodovia BR-101 em trecho associado a um dos remanescentes de Mata Atlântica mais importantes do país: o bloco Linhares-Sooretama, que abriga a última população da espécie no estado do Espírito Santo. O projeto para duplicação de toda BR-101 já foi aprovado e a concessionária responsável pelas obras já iniciou as primeiras ações no estado, mas ainda não há estudo de impacto ambiental para o projeto de duplicação ou o planejamento de medidas especiais para evitar ou reduzir o risco de atropelamento de fauna na região. Desta forma, para minimizar os impactos associados à BR-101, é recomendada a não duplicação do trecho de 15 quilômetros que atravessa o bloco Linhares-Sooretama. Sugere-se, alternativamente, o desvio do traçado atual da Rodovia BR-101 ou a construção de viadutos para a fauna nos pontos mais críticos, intercalando estas passagens com redutores eletrônicos de velocidade e placas educativas e de advertência.
\end{abstract}

Palavras-chave: grandes felinos, manejo, monitoramento, área protegida, espécie ameaçada.

\section{Introduction}

Roads cause alterations to landscape as a result of fragmentation and habitats deterioration, resulting in several negative effects on animal and plant communities, which affect the integrity of terrestrial and aquatic ecosystems (Trombulak and Frissell, 2000). The negative effects of roads are associated with mortality of specimens during 
the road construction, mortality of animals due to collision with vehicles, modification of individual behavior, physical and chemical alteration of the environment, spread of exotic species and change in land use by humans, favoring the access to remote or little accessible areas (Trombulak and Frissell, 2000).

The collisions with vehicle, in particular, are identified as a major cause of mortality in wild animal populations in different parts of the world (Forman and Alexander, 1998). This issue has been exacerbated by the increase of traffic intensity and gradual increase in the number of roads permeating natural areas (Hughes et al., 1996). According to Trombulak and Frissell (2000), few species of terrestrial vertebrates are immune to this threat and roads are probably surpassing hunting as the main direct cause of mortality of terrestrial vertebrates in recent decades (Forman and Alexander, 1998).

The medium and large size mammals are especially susceptible to roadkill on two-lane roads and high-speed tracks (Forman and Alexander, 1998). Roads represent a particular threat to the conservation of carnivores due to their high mobility and large home range requirements, which constantly expose them to the risk of struck and kill in landscapes crossed by roads (Noss et al., 1996).
Among the carnivores, the death of felines as a result of collision with vehicles has been recorded in several parts of the world, including large species such as tiger (Panthera tigris Linnaeus, 1758) (Gruisen, 1998a), lion (Panthera leo Linnaeus, 1758) (Drews, 1995), leopard (Panthera pardus Linnaeus, 1758) (Gruisen, 1998a, 1998b; Baskaran and Boominathan, 2010), jaguar (Panthera onca Linnaeus, 1758) (Fischer et al., 2003; Cullen-Júnior, 2006; São Paulo, 2006) and puma (Puma concolor Linnaeus, 1771) (Maehr et al., 1991; Cáceres et al., 2010). The smaller species are also affected, such as ocelots (Leopardus pardalis Linnaeus, 1758) (Cáceres et al., 2010), Geoffroy's cat (Leopardus geoffroyi d'Orbigny and Gervais, 1844) (Attademo et al., 2011), oncilla (Leopardus tigrinus Schreber, 1775) (Hegel et al., 2012) and jaguarundi (Puma yagouaroundi É. Geoffroy, 1803) (Cunha et al., 2010; Hegel et al., 2012). Roadkill may have a substantial effect on the demography of the populations most often affected by collision with vehicles (Trombulak and Frissell, 2000) and have become a growing problem in recent years (Baskaran and Boominathan, 2010), representing an even greater threat to threatened species whose populations are restricted to a small number of individuals frequently in contact with roads.

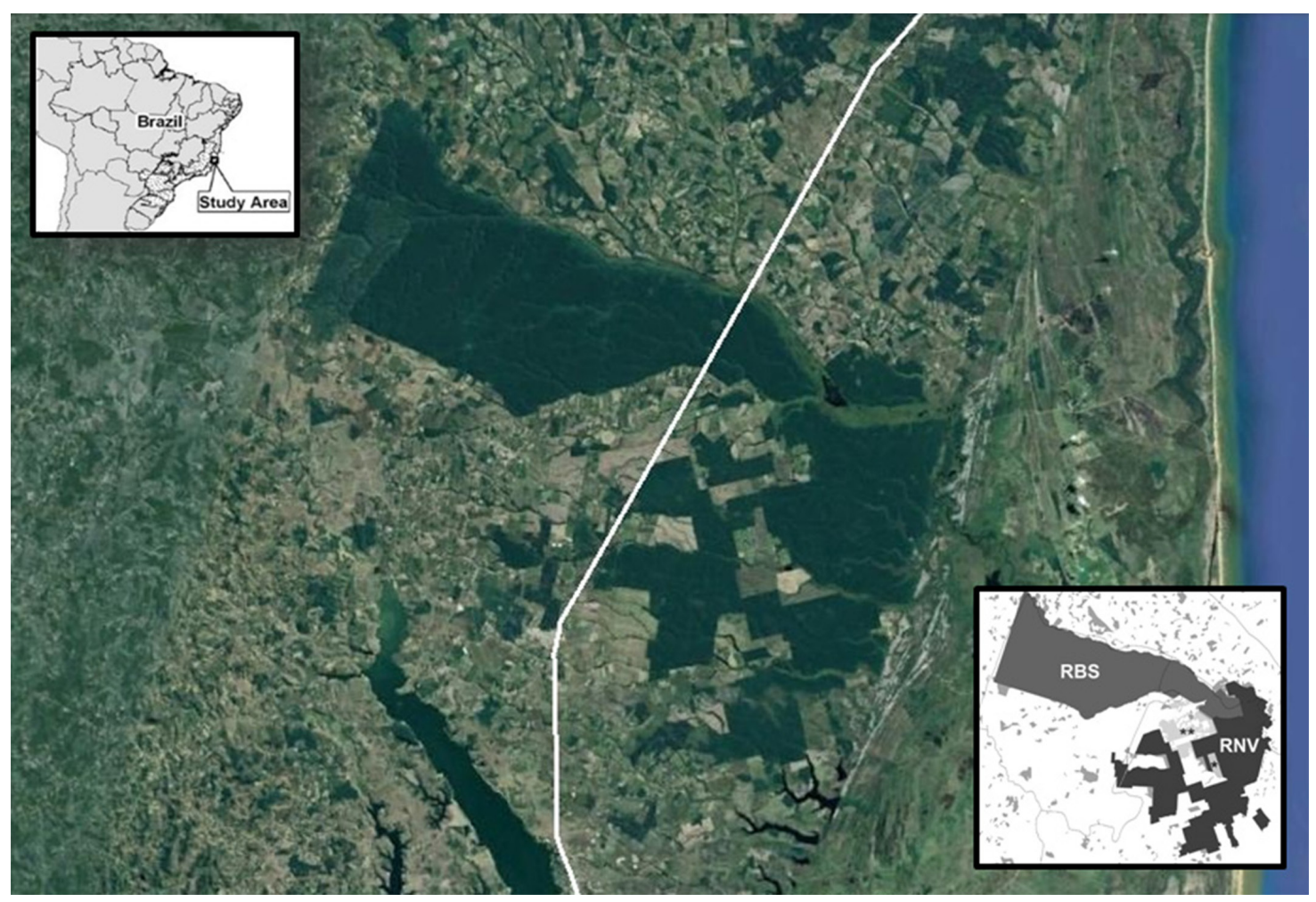

Figure 1. Image of the Linhares-Sooretama block: Sooretama Biological Reserve (RBS), Vale Natural Reserve (RNV), Recanto das Antas Natural Heritage Private Reserve (**) and Mutum Preto Natural Heritage Private Reserve (*), in the northern portion of the state of Espírito Santo, showing the BR-101 Highway (white line). The location of the reserves in the Atlantic Forest (dotted area) [top insert] and the limits of RBS and RNV with the surrounding Atlantic Forest remnants (light grey polygons) [lower insertion] are also shown. Background image source: Google Earth (2012 Cnes/Spot Image; Image U.S. Geological Survey; Data SIO, NOAA, U.S. Navy, NGA, CEBCO). 
This communication reports the roadkill of a jaguar on the BR-101 Highway, in a sector where this road crosses the two largest protected areas in the state of Espírito Santo, southeastern Brazil. These two areas are among the most important nature reserves of the Atlantic Forest in the country and are one of the last strongholds of the jaguars in this biome. A brief review about this issue and the proposition of measures to minimize the impacts of roadkill on that sector of BR-101 are also presented and discussed.

\section{Study Area}

The Sooretama Biological Reserve (Reserva Biológica de Sooretama - RBS: 24,250 ha) and the Vale Natural Reserve (Reserva Natural Vale - RNV: 22,711 ha) are located in the northern portion of the state of Espírito Santo. These two reserves, together with other two smaller private protected areas (the Recanto das Antas Natural Heritage Private Reserve: 2,212 ha; and the Mutum Preto Natural Heritage Private Reserve: 379 ha), form a single block of native vegetation (Linhares-Sooretama block) which corresponds to more than $10 \%$ of the remaining area covered by forests in the entire state (Fundação SOS Mata Atlântica, 2014). The BR-101 Highway traverses the RBS on a stretch of about $5.7 \mathrm{~km}$ that harbors native forest on both sides of the road (Figure 1). Other $8.5 \mathrm{~km}$ of the BR-101 Highway are associated with RNV and neighboring rural properties, which include the boundary between this reserve and areas with varied land use types (eucalyptus and papaya plantations, pastures, among others) and remnants of native vegetation (Figure 1). The stretch associated with RBS has five wildlife crossings - three of them associated with drainages (shackle type) and the other two are droughts (tunnel type). There are no wildlife crossings in the stretch associated with RNV and neighboring properties. The wildlife roadkill occurring in the stretch associated with RBS have been systematically recorded since August 2010 by the staff of this reserve; but the effectiveness of the wildlife crossings has not been assessed yet.

\section{The Jaguar and the BR-101 Highway}

The monitoring of the jaguar population was started in the RNV in 2005, and nine individuals have been identified in this reserve by camera traps thus far (Srbek-Araujo, 2013). For RBS, the survey by camera traps was not systematic and much less exhaustive, and resulted in the record of a single individual, apart from those recorded in RNV (Srbek-Araujo, 2013). There is no data available to estimate the frequency with which jaguars are crossing between the portions of forest to the east and west side of the BR-101 Highway. Nevertheless the intense traffic of small and large vehicles (especially B-train type trucks) in this important transport route that traverses from south to north of Brazil doubtless implies that this road is a constant threat to the conservation of jaguars in the region.

On August 31, 2000 a female jaguar was found dead in the stretch of BR-101 Highway associated with RBS; and removed to the collection of Mello Leitão Biology Museum (municipality of Santa Teresa, Espírito Santo state). The analysis of the skull and mandible confirmed that it was an adult (MBML-Mamíferos 3486).

Roadkill events of other feline species have been occasionally recorded in BR-101 Highway in the stretch associated with RBS and RNV. These records include the death of a puma, on April 7, 2009, although the species of small cats (especially Leopardus spp.) are the most commonly felids affected in the region (unpublished data). There are no prior or subsequent official records of jaguar roadkill in the region, and the event reported in this communication is the only one known. Nonetheless, we should not rule out the occurrence of past and recent additional events which have not been reported to local authorities or researchers working in the region. Further, the death of the specimens struck by vehicles may not be instantaneous and the animals hit by vehicles may take refuge inside the reserves, dying later from the injuries.

The death of jaguars due to roadkill is not uncommon in Brazil. Although these records are rare in the scientific literature, the reports of fatal accidents involving this species has been published in newspapers and online news and can be easily found in search sites on the Internet (keywords: "atropelamento onça-pintada"). Some of the most recent records (registered until december 2013) dates from September 2013 (in the BR-163 Highway, between the municipalities of Sorriso and Lucas do Rio Verde, state of Mato Grosso); October 2012 (in the MT-242 Highway, near the municipality of Sorriso, state of Mato Grosso); and December and August 2012 (in the BR-262 Highway, between the municipalities of Corumbá and Miranda, state of Mato Grosso do Sul). At least four kills of jaguar, including a cub, have been recorded in the last five years in the stretch of road between Corumbá and Miranda. And this stretch is considered the most problematic section of BR-262 Highway in Mato Grosso do Sul regarding to the kill of wild animals.

In the Atlantic Forest, records of jaguar roadkill are linked to protected areas that function as the last refuges of the species in the biome. In March 2009, the death of a specimen was recorded on BR-469 Highway, inside the Foz do Iguaçu National Park (state of Paraná). In November 2002 (Cullen-Júnior, 2006) and in June 2001 (São Paulo, 2006), two jaguar roadkill were recorded on the SP-613 Highway, which crosses the Morro do Diabo State Park (state of São Paulo). Unfortunately, these events are not the only records of jaguar roadkill known in Atlantic Forest. In this scenario, the roads and highways adjacent to or crossing through protected areas function as additional sources of local extinction for the species. And it worsens the jaguar's case in the Atlantic forest because all remaining populations in this biome are isolated, extremely reduced and in contact with roads. 
The BR-101 Highway will be duplicated in the entire state of Espírito Santo (the project has been approved by government) and the company responsible by the work has already started the first activities in the state. Nevertheless, there is no environmental impact assessment already done for this project neither for the northern portion of the state where Linhares-Sooretama block is located. Further, so far there is no planning for specific measures to either avoid or reduce the risk of wildlife roadkill on the stretch between the RBS and RNV (information obtained from the Regional Superintendence of the National Department of Transport Infrastructure - DNIT, in Linhares city, in December 2012) $)^{1}$. The conservation of the jaguar population in Linhares-Sooretama block will surely be further impaired if alterations on the design of road duplication project were not done or if efficient mechanisms for wildlife road crossing are not implemented.

\section{Highway Duplication and Impacts on Wildlife}

The impacts of roads on wildlife populations are more dramatic in multilane roads. Reilly and Green (1974) showed that the duplication of an interstate road in Michigan (USA) resulted in an immediate increase of approximately $500 \%$ on the annual mortality rate of white-tailed deer (Odocoileus virginianus), compared to the average roadkill rate recorded over the four years prior to duplication. Thereafter there was a gradual decrease in crashes involving deer, until the annual rate remained, on average, twice higher than the rate recorded prior to duplication (Reilly and Green, 1974). Besides the increased risk of roadkill per se, road duplication may also reduce or stop the flow of specimens between RNV and RBS as some species are reluctant to venture into open areas. Generally, the greater is the distance to be crossed, the lower is the probability of movement for various vertebrate groups. Once acting as inhibitors of movement or as barriers to the movement of species, the roads contribute to the fragmentation of habitats and populations, disrupting the flow of several important natural processes for the maintenance of species (Forman and Alexander, 1998; Trombulak and Frissell, 2000).

\section{Wildlife Roadkill Mitigation Measures and Costs}

Given that species respond differently to road crossing mechanisms, most of such structures are selectively permeable to wildlife (Clevenger and Waltho, 2005). Its use by animals is a function of several factors, including the characteristics of the structure itself, such as height,

Due to the increasing awareness and mobilization of the academic community and NGOs (especially from the end of 2014), the duplication of the BR-101 is now being regarded as a real problem to the biodiversity of the Espírito Santo. As a consequence, studies to assess the environment impacts of this lines duplication on the stretch crossing the Linhares-Sooretama block are now finally underway. width, length (distance to go), noise level (resulting from vehicle traffic) and the presence or amount of plant cover at the entrance of the passes; and local environmental characteristics, such as distance from the nearest water body and the existence of human activity nearby (Clevenger and Waltho, 2005). Additionally, the use of the structures may vary seasonally (Clevenger and Waltho, 2005), and the passes can be partially successful for a given species, once some individuals cannot find it (Foster and Humphrey, 1995), making its efficiency variable between individuals. It has also been observed that the effect of wildlife crossings is not immediate, requiring a period of habituation for wildlife to use the structures. Habituation may require several years depending on the species, the previous experiences of specimens and the learning of individuals, as well as their ability to adjust their own behavior (Clevenger et al., 2002).

The efficiency of mitigation measures depends on their ability to maximize the connectivity along the roads, making them permeable to the largest number of species. Therefore, the road construction projects should include a variety of crossing mechanisms, considering structures with different shapes and dimensions (Clevenger and Waltho, 2005). Further, the mitigation strategies do not end with the installation of the crossing structures. It is also necessary to ensure that the structures remain functional over time, which requires continuous monitoring (Clevenger and Waltho, 2005).

It is known that not all negative effects of roads can be remedied, and they continue to represent sources of mortality for several species even after the implementation of mitigation measures (Trombulak and Frissell, 2000). Nevertheless, the conservation of various species in the state of Espírito Santo, which occur only or have the more representative population of the entire state in the Linhares-Sooretama block, will be threatened if not using efficient mechanisms to reduce vehicle collisions with wildlife in BR-101.

In addition to the negative effects already discussed, road accidents involving wildlife also have social and economic costs and should, therefore, be viewed as important socio-economic and traffic safety issues (Hughes et al., 1996). Conservative estimates indicate, for example, that approximately 415 accidents involving deer occur every year in the United Kingdon (Langbein, 2011). Only in England, about $46 \%$ of accidents that resulted in injured people, including fatal accidents, were attributed to collisions with deer, which were mentioned in the official descriptions of 133 accidents/year on average (Langbein, 2011). The economic damage caused by this type of road accident is estimated at over $£ 28$ million for the entire United Kingdon annually, including health and medical costs, property damage, insurance administration and legal and court costs, among other expenses (Langbein, 2011). In the United States of America, the values are even higher. About 26,000 accidents involving wild large size animals are recorded annually in the country, considering those that result in drivers and / or passengers injured, and about 
200 fatalities are recorded every year due to accidents of this type (Huijser et al., 2008). The direct financial impact of accidents involving wildlife is estimated at nearly US\$ 8.4 billion/year in this country (Huijser et al., 2008). Although such information is not available for Brazil yet, it is likely that accidents involving wildlife also incur in large costs. The road network in the country comprises more than 1.7 million $\mathrm{km}$ and a third of this is located in the southeastern region (ANTT, 2009), where most of the Atlantic Forest remnants are found.

It is both difficult and controverse to monetarized the costs of roadkill on biodiversity, but there is a noteworthy case of a roadkilled jaguar at the SP-613 Highway within Morro do Diabo State Park that deserves attention. The public prosecutor in charge of this case established a fine for damages to be paid by the company responsible for the truck involved in the accident. Although the animal has an intrinsic value, not measurable, the amount to be paid by the company was estimated based on the caring costs of a jaguar cub, from its birth until its return to nature, including expenses associated to training and release the animal. The final value reached the sum of about US\$200,000 and was reversed to the purchase of equipment for continuing jaguar studies in the region (Chiaravalloti, 2011).

\section{The Proposal for Linhares-Sooretama block}

Given the uncertainties and difficulties in defining the best design for the crossing structures, as well the high impact represented by the loss of specimens or by the partition of the jaguar population between RNV and RBS, the duplication of the BR-101 Highway is not recommended for the $15 \mathrm{~km}$ stretch traversing the Linhares-Sooretama block. The construction of new wildlife crossings for both protected areas and the improvement of existing crossings structures in RBS area (applying modern concepts related to road ecology), plus the installation of electronic speed monitoring devices, educational plates and plates warning about wildlife crossing, are highly recommended.

Other alternatives should be also evaluated, although they might represent more expensive options, such as: (1) the deviation of the current route of the BR-101 Highway, bypassing the Linhares-Sooretama block (by its west or east side); or (2) the construction of overpasses to fauna in the most critical points. The first alternative, which would include shorter and curved sections of road, would help to reduce the vehicle speed; and the vehicle speed is an important factor affecting roadkill rates (Forman and Alexander, 1998). The overpasses to fauna should to keep the area adjacent to and above the overpasses covered with native herbaceous and shrubby vegetation and without artificial lighting. Similar structures have been adopted in Europe and North America to minimize the negative effects of roads on wildlife (Clevenger and Huijser, 2011). These overpasses should be interspersed with electronic speed monitoring devices and warning and educational plates. The installation of fences to guide wildlife for the crossing points should also be evaluated (Clevenger and
Huijser, 2011). We consider that the ecomomic costs of these alternatives are high but might nevertheless compensate in long term the damage caused to vehicles, people (injuries and fatal accidents) and wildlife.

Apart from the revaluation of the duplication project, it is also necessary to monitor systematically the wildlife roadkill in the region. This will help to evaluate the effectiveness of wildlife road crossings and to identify the most critical points, as well the most affected species, contributing to a better understanding of the impacts of the BR-101 Highway on the community of vertebrates present in the Linhares-Sooretama block. The monitoring should be started before the beginning of the duplication work to assess the current pattern of roadkill and to identify the points that require mitigation actions, whether wildlife crossings (under and/or overpasses), fences, electronic speed monitoring devices or plates. As previously mentioned, continuing the monitoring after the completion of the lines duplication is extremely important for the proper assessment of the efficiency and functionality of the implemented structures.

\section{Final Considerations}

Even if the roadkill of big cats are viewed as sporadic events in the BR-101 Highway, the negative effect of the loss of a single specimen is serious enough for the local population of jaguars, which is extremely reduced (maximum population size estimated at approximately 18-24 individuals; Srbek-Araujo, 2013). Furthermore, the disruption of the individual flow between the two reserves, due to failure in attempts to cross the BR-101 Highway or its transformation into a barrier for the species after its duplication, may lead to the division of the population into two smaller subpopulations. These, in turn, will become even more susceptible to demographic and genetic problems. In this scenario, the duplication of the BR-101 Highway can result in invaluable biodiversity losses to the state of Espírito Santo. The Linhares-Sooretama block shelter several other threatened species both nationally and worldwide, such as the giant armadillo (Priodontes maximus Kerr, 1792), the tapir (Tapirus terrestris Linnaeus, 1758), the white-lipped peccary (Tayassu pecari Link, 1795), the thin-spined porcupine (Chaetomys subspinosus Olfers, 1818) and the red-billed curassow (Crax blumenbachii Spix, 1825), among several others. We highlight that the jaguar population in the Linhares-Sooretama block is the last population in the entire state of Espírito Santo and one of the last populations in the Atlantic Forest biome as a whole (Beisiegel et al., 2012). Thus, adopting actions that contribute to its long term conservation is extremely important and urgent.

\section{Acknowledgements}

The data in this manuscript are part of the research project "Population Size, Density and Habitat Use by Jaguar (Panthera onca, Carnivora, Felidae) in Reserva Natural 
Vale, Linhares, Espírito Santo / Brazil”. We thank Vale S.A. for their financial support. A. G. Chiarello is sponsored by CNPq (303273/2008-9 and 306848/2011-2).

\section{References}

Agência Nacional de Transportes Terrestres - ANTT, 2009. Anuário estatístico dos transportes terrestres - período 2004 a 2008. 1.1.3 - extensão total, em quilômetros, das rodovias, por região e UF - 2004-08. Brasília: ANTT. Available from: $<$ http://appweb2.antt.gov.br/InformacoesTecnicas/aett/aett_2009/ principal.asp>. Access in: 28 Mar. 2013.

ATTADEMO, AM., PELTZER, PM., LAJMANOVICH, RC., ELBERG, G., JUNGES, C., SANCHEZ, LC. and BASSÓ, A., 2011. Wildlife vertebrate mortality in roads from Santa Fe Province, Argentina. Revista Mexicana de Biodiversidad, vol. 82, p. 915-925.

BASKARAN, N. and BOOMINATHAN, D., 2010. Road kill of animals by highway traffic in the tropical forests of Mudumalai Tiger Reserve, southern India. Journal of Threatened Taxa, vol. 2, p. 753-759.

BEISIEGEL, BM., SANA, DA. and MORAES-JÚNIOR, EA., 2012. The jaguar in the Atlantic Forest. Cat News Special Issue, vol. 7, p. 14-18.

CÁCERES, NC., HANNIBAL, W., FREITAS, DR., SILVA, EL., ROMAN, C. and CASELLA, J., 2010. Mammal occurrence and roadkill in two adjacent ecoregions (Atlantic Forest and Cerrado) in south-western Brazil. Zoologia, vol. 27, p. 709-717.

CHIARAVALlOTI, RM., 2011. “Ai Meu Deus! Matei a onça do Globo Rural!”. Diário do Verde. Available from: <http:// diariodoverde.com/ai-meu-deus-matei-a-onca-do-globorural/\#ixzz2O0v1gg00>. Access in: 20 Mar. 2013.

CLEVENGER, AP. and WALTHO, N., 2005. Performance indices to identify attributes of highway crossing structures facilitating movement of large animals. Biological Conservation, vol. 121, p. $453-464$.

CLEVENGER, AP., CHRUSZCZ, B., GUNSON, K. and WIERZCHOWSKI, J., 2002. Roads and wildlife in the Canadian Rocky Mountain Parks - movements, mortality and mitigation. Banff: Parks Canada. 432 p. Final report to Parks Canada.

CLEVENGER, T. and HUIJSER, MP., 2011. Handbook for design and evaluation of wildlife crossing structures in North America. Bozeman: Western Transportation Institute. 204 p. Report to the Federal Highway Administration.

CULLEN-JÚNIOR, L., 2006. Jaguar as landscape detectives for the conservation in the Atlantic Forest of Brazil. Canterbury: University of Kent. 178 p. PhD thesis in Conservation and Ecology.

CUNHA, HF., MOREIRA, FGA. and SILVA, SS., 2010. Roadkill of wild vertebrates along the GO-060 road between Goiânia and Iporá, Goiás State, Brazil. Acta Scientiarum. Biological Sciences, vol. 32, p. 257-263.

DREWS, C., 1995. Road kill of animals by public traffic in Mikumi National Park, Tanzania with notes on baboon mortality. African Journal of Ecology, vol. 33, p. 89-100.

FISCHER, WA., RAMOS-NETO, MB., SILVEIRA, L. and JACOMO, AT., 2003. Human transportation network as ecological barrier for wildlife on Brazilian Pantanal-Cerrado corridors. In IRWIN, CL., GARRETT, P. and MCDERMOTT, KP. (Eds).
Proceedings of the 2003 International Conference on Ecology and Transportation, 2003. Lake Placid. North Carolina: Center for Transportation and the Environment/ North Carolina State University. p. 182-194.

FORMAN, RTT. and ALEXANDER, LE., 1998. Roads and their major ecological effects. Annual Review of Ecology Evolution and Systematics, vol. 29, p. 207-231.

FOSTER, ML. and HUMPHREY, SR., 1995. Use of highway underpasses by Florida Panthers and other Wildlife. Wildlife Society Bulletin, vol. 23, p. 95-100.

Fundação SOS Mata Atlântica. Instituto Nacional de Pesquisas Espaciais - INPE, 2014. Atlas dos Remanescentes Florestais da Mata Atlântica - Período 2012-2013. São Paulo: Fundação SOS Mata Atlântica/ Instituto Nacional de Pesquisas Espaciais. Available from: <https://www.sosma.org.br/wp-content/uploads/2014/05/ atlas_2012-2013_relatorio_tecnico_20141.pdf $>$. Access in: 23 Nov. 2014

GRUISEN, JV., 1998a. Rajasthan. Tiger Link, vol. 4, p. 10-11. GRUISEN, JV., 1998b. Uttar Pradesh. Tiger Link, vol. 4, p. 14.

HEGEL, CGZ., CONSALTER, GC. and ZANELLA, N., 2012. Mamíferos silvestres atropelados na rodovia RS-135, norte do Estado do Rio Grande do Sul. Biotemas, vol. 25, p. 165-170.

HUGHES, WE., SAREMI, AR. and PANIATI, JF., 1996. Vehicle-animal crashes: an increasing safety problem. Institute of Transportation Engineers Journal, vol. 66, p. 24-28.

HUIJSER, MP., MCGOWEN, P., FULLER, J., HARDY, A., KOCIOLEK, A., CLEVENGER, AP., SMITH, D. and AMENT, R., 2008. Wildlife-vehicle collision reduction study: report to congress. Bozeman: Western Transportation Institute/ Montana State University. 232 p.

LANGBEIN, J., 2011. Monitoring reported deer road casualties and related accidents in England to 2010. Deer initiative research report to the Highways Agency. Wrexham: The Deer Initiative. 63 p.

MAEHR, DS., LAND, ED. and ROELKE, ME., 1991. Mortality patterns of panthers in southwest Florida. In Proceeding of Annual Conference of Southeast Association of Fish and Wildlife Agencies, 1991. White Sulphur Springs. Jefferson City: SEAFWA. p. 201-207.

NOSS, RF., QUIGLEY, HB., HORNOCKER, MG., MERRILL, T. and PAQUET, PC., 1996. Conservation biology and carnivore conservation in the Rocky Mountains. Conservation Biology, vol. 10, p. 949-963.

REILLY, RE. and GREEN, HE., 1974. Deer mortality on a Michigan interstate highway. The Journal of Wildlife Management, vol. 38 , p. 16-19.

São Paulo. Secretaria do Meio Ambiente do Estado de São Paulo, 2006. Parque Estadual do Morro do Diabo: plano de manejo. Santa Cruz do Rio Pardo: Editora Viena. 311 p.

SRBEK-ARAUJO, AC., 2013. Conservação da Onça-pintada (Panthera onca Linnaeus, 1758) na Mata Atlântica de Tabuleiro do Espirito Santo. Belo Horizonte: Universidade Federal de Minas Gerais. 224 p. PhD thesis in Wildlife Ecology, Conservarion and Management.

TROMBULAK, SC. and FRISSELL, CA., 2000. Review of ecological effects of roads on terrestrial and aquatic communities. Conservation Biology, vol. 14, p. 18-30. 